\title{
ANTECEDENTS OF TRUST TOWARDS THE ATTITUDE OF CHARITABLE ORGANISATION IN MONETARY PHILANTHROPIC DONATION AMONG GENERATION-Y
}

\author{
Siti Hasnah Hassan ${ }^{1 *}$, Tajul Ariffin Masron', Noor Mohamed², and \\ Ramayah Thurasamy ${ }^{1,3}$
}

${ }^{1}$ School of Management, Universiti Sains Malaysia, 11800 USM Pulau Pinang, Malaysia ${ }^{2}$ Global Envdk Sdn. Bhd., 3A, Bukit Jalil Golf \& Country Resort, Jalan Jalil Perkasa 3, 57000 Bukit Jalil, Kuala Lumpur, Malaysia

${ }^{3}$ Visiting Professor at Faculty of Cognitive Science and Human Development, Universiti Malaysia Sarawak, 94300 Kota Samarahan, Sarawak, Malaysia

*Corresponding author: siti.hassan@usm.my

Published online: 29 June 2018

To cite this article: Hassan, S.H., Masron, T.A., Noor, M., and Ramayah, T. (2018). Antecedents of trust towards the attitude of charitable organisation in monetary philanthropic donation among generation-Y. Asian Academy of Management Journal, 23(1), 53-78. https://doi.org/10.21315/aamj2018.23.1.3

To link to this article: https://doi.org/10.21315/aamj2018.23.1.3

\begin{abstract}
Monetary philanthropic donation, which is held through charitable organisation (CO), is known as a voluntary contribution in the form of money. The purpose of this donation is to improve public's welfare, where there is little to no commensurate reward given to the donor. Furthermore, the organisation is fully responsible for the money used for donation. Therefore, an understanding in regards of the donor's attitude and perception is essential for $\mathrm{CO}$, in order to improve the philanthropic behaviour displayed by the public. Following that, the purpose of this research is to identify the relationship between trust disposition, perceived ability, perceived integrity, perceived benevolence, the attitude towards $\mathrm{CO}$, and the influence of these factors towards young generation behaviour during monetary philanthropic donation. Pertaining to these factors, through self-administered questionnaire, a survey was conducted to collect data from 258 respondents from Generation-Y or Gen-Y in Malaysia. The data was then analysed using SmartPLS 3.2.6. Based on the findings obtained from the survey, it was shown that philanthropic monetary donation held through $\mathrm{CO}$ is indirectly influenced by the perceived ability and integrity displayed through the public's attitude towards $C O$. Out of all factors, perceived integrity, perceived ability, and perceived benevolence were found to directly influence the attitude
\end{abstract}

(C) Asian Academy of Management and Penerbit Universiti Sains Malaysia, 2018. This work is licensed under the terms of the Creative Commons Attribution (CC BY) (http://creativecommons. org/licenses/by/4.0/). 
displayed by public towards CO. On the contrary, it was a surprising fact that there is a small relation between trust disposition and the public's attitude towards $C O$. Besides, the attitude displayed towards $\mathrm{CO}$ does not mediate the relationship between trust disposition and philanthropic behaviour. The findings provide valuable insight to scholars, marketing practitioners, and COs in their understanding of the complex philanthropic behaviour shown by individuals.

Keywords: trust disposition, perceived ability, perceived integrity, perceived benevolence, charitable organisation $(\mathrm{CO})$

\section{INTRODUCTION}

Philanthropy can be characterised as the voluntary effort of improving the wellbeing of people. It can be briefly said that philanthropy is a personal act done for the benefits of the public (Payton, 1988); more precisely, it is referred as contributions in any forms that are voluntarily given to benefit the public (Schuyt, Smit, \& Bekkers, 2013). One of the common philanthropic behaviour is shown through monetary donation. This type of behaviour is manifested from contributions in the form of cash, time, or other resources to charitable organisations (CO). According to Alhidari (2014), CO is a voluntary, formal, self-governed, partially independent, non-profit distributing, and non-political or religious organisation. The traditional channel for $\mathrm{CO}$ normally consists of direct contribution to the needy, especially when the donors and beneficiaries often come to contact to each other, or when the donor knew where beneficiaries lived. Consequently, COs have become the main channel for individuals' monetary donations. COs are probably the most publicly recognised organisation within the non-profit sector. COs are formal entities that are separated from government and business. They are self-governing, non-profit distributing, benefiting from philanthropic donations and voluntarism, and are not political or religious.

Previous researchers have reported that monetary donation is a preferable act of charity displayed by individuals (Hsu, Liang, \& Tien, 2005). This is because through this act, individuals are able to give significant contribution to the monetary donation market every year (Alhidari, 2014; Giving USA, 2013). Furthermore, monetary donation behaviour is commonly considered as a type of helping behaviour to civic engagement (Jones, 2006). Meanwhile, Lyons (2001, p. 46) defines monetary donation as a "voluntary gift in the form of money, in order to aid the public." Out of all definitions, the widely accepted definition of monetary donation is the one created by Salamon (2012) where monetary donation is defined as "the personal action of contributing money for public purposes" (p. 10). 
According to the report by The World Giving Index, almost one-third out of the overall world's population had contributed money for charity purposes, while onefifth of the world's population had volunteered themselves (Giving USA, 2016). On the other hand, $45 \%$ of the world's population had offered help to strangers (Ramesh, 2011). According to Giving USA (2016), a healthier American economy leads to $7.1 \%$ of the rate of charitable contribution. This can be proven by how individuals have donated approximately $\$ 358.38$ billion for charity purposes in year 2014. In light of Charities Aid Foundation (CAF) World Giving Index, the global youths are encouraging the increase of public's participation into volunteer work. Since 2011, the highest increment of volunteer work was resulted from the participation of youngsters within the age of 15 to 24 years old. Initially, youngsters from this range of age were the least likely to volunteer in 2008. However, they became the group of age who was the second most likely to volunteer in 2012. As a result, there was an increase of the rate of participation into volunteer work in 2012 , which was from $18.4 \%$ to $20.6 \%$. On the other hand, in Malaysia, only $32 \%$ of the population performed monetary donation to CO (Ramesh, 2011).

The philanthropic behaviours displayed by individuals can be categorised with three primary approaches: sociological, psychological, and multidimensional. In sociological approach, sociologists emphasise the importance of social standards in promoting philanthropic behaviour. In fact, individuals act in accordance to social standards especially when they are emphatically involved with mediators, such as social gatherings. The examples of places where social gatherings are involved are families, mosque, or church (Alhidari, 2014). In psychological approach, philanthropic behaviours are influenced by the subjective and passionate actions displayed by the donor. According to this approach, people who provide for others experience several psychological rewards, such as personal satisfaction. In general, the literature acknowledges two psychological motivations: altruistic and egoistic motivations. Moreover, the existing literature indicates that philanthropic behaviour is a result of a combination of motivations.

Moreover, the thought processes of individuals, their motivations, emotions, and their experiences are also the important elements of the philanthropic behaviours displayed by them (Bartolini, 2005). Therefore, identification of the influential factors that affect public's monetary philanthropic behaviour holds a high importance. Furthermore, despite the significant influence caused by the donors' personal factors on philanthropic behaviours displayed by public, these factors do not result in the increase of charitable contribution. In spite of the generosity shown by the individual donors, due to the distance between the donors and recipients, it is required for the donors to place their entire trust on the $\mathrm{CO}$ to channel their donation (Hou, Zhang, \& King, 2017; Ritchie, Swami, \& Weinberg, 1999). 
To illustrate this, before donations are contributed to COs, the belief that these organisations are trustworthy, reliable, able to transmit its mission effectively, and use the donation money wisely needs to be instilled within the donors (LaidlerKylander, Quelch, \& Simonin, 2007; Shehu, Becker, Langmaack, \& Clement, 2016).

There have been numerous studies conducted in the attempt to examine individual's behaviour during monetary donation. In spite of this fact, there are still a scarce number of studies focusing on the creation of a complete model in understanding the behaviour displayed during monetary donation, especially when the donation is conducted through CO. Furthermore, a large portion of the past inquiries regarding the public's behaviour during monetary donation was directed to developed Western economies (Ranganathan \& Sen, 2012). Besides, a very few number of the inquiries explored the role of $\mathrm{CO}$ in the behaviours displayed by individuals during monetary donation. This matter was focused particularly in developing countries, such as Malaysia. In Malaysia, the role of CO can be seen from this example: the government grants tax deductions to avid philanthropists, who may donate large sums of money from their income for public, civic, charitable, or religious purposes. This causes the donation rate to be up to $7 \%$ tax deduction provided that the monetary donation is held in approved institutions, organisations, sports bodies, projects, and national interests examined by the Ministry of Finance.

Therefore, the present study focuses on individual monetary donations, which are conducted through COs. Furthermore, this study attempts to provide some insight on how the antecedents of trust, which are measured by trust deposition, perceived ability, perceived integrity, and perceived benevolence trust bring influence to the attitudes displayed during monetary donation in COs.

\section{THE MODEL OF TRUST TOWARDS AN INDIVIDUAL'S BEHAVIOUR DURING MONETARY PHILANTHROPIC DONATION}

There have been heated arguments going on regarding the view of monetary philanthropic donation. The arguments particularly concerned on whether philanthropic behaviours derive from individuals' personal factors or they are influenced by other factors, such as social and environmental factors. However, in recent years, numerous scholars have started to adapt to a multidimensional view on philanthropic behaviour, which includes the motivations for contributing and the motivations for decision-making processes during monetary donation (Burgoyne, Young, \& Walker, 2005); the role of trust and commitment (Sargeant 
\& Lee, 2002a; Sargeant, West, \& Ford, 2004); the role of social relations (Radley \& Kennedy, 1995); the influence of personal and social factors on the behaviours displayed during monetary giving (Smith \& McSweeney, 2007); and the role of a CO's image and reputation in the donors' decisions (Bennett \& Ali-Choudhury, 2009). The level of donor trust not only affects the repeated donation and the increase in the donation amounts (Burnett, 2002; Sargeant \& Lee, 2002b; Sargeant et al., 2004), it also helps the donors' to believe that their funds will be used appropriately by the recipient COs (Stride, 2006) and in support of the organisation's legal and moral obligations (Sargeant \& Lee, 2002b). Thus, in this paper, the aim is to see how trust plays a role in the monetary donation through $\mathrm{CO}$.

Mayer, Davis, and Schoorman (1995, p. 712) propose an integrative definition of trust as:

The willingness of a party [trustor] to be vulnerable to the actions demonstrated by another party [trustee], based on the expectation that the other [trustee] will perform a particular action important to the trustor, irrespective of the ability to monitor or control that other party [trustee].

The theoretical foundation of trust in COs can be conceptualised as a multidimensional construct by previous researchers (Grabner-Kräuter \& Kaluscha, 2003) which stated that there is evidence to support the critical role that trust in influencing the relationships between companies and customers. Mayer et al. (1995) propose a generic typology of trust, which consists of three dimensions: ability, benevolence, and integrity. Furthermore, trust is conceptualised in this study in terms of the trustor's beliefs in the trustee's ability, benevolence, and integrity. These three dimensions are conceptually distinct from each other because they tap into different elements of cognitive and affective abstraction of trust. Another element of cognitive and affective abstraction of trust is the personal deposition to trust of an individual. This predictor will influence the donor's trust, followed by the donor's attitude towards the CO.

\section{The Perceived Ability of Charitable Organisation}

Perceived ability is defined as "a set of skills, competencies, and characteristics that enable a party to have influence over some particular domain" (Mayer et al., 1995, p. 717). According to Bhattacherjee (2002), perceived ability refers to the trustor's impression on the trustee's capabilities and knowledge in accordance to the expected behaviour. To illustrate this, the higher the level of perceived ability, the higher the probability for the organisation to gain trust from the purchaser (Morgan 
\& Hunt, 1994). In other words, it can be stated that the donor's attitude towards $\mathrm{CO}$ is developed through individuals' perception. This perception mainly concerns on whether the $\mathrm{CO}$ has the competency to transfer the donor's contribution to the desired cause and to assist the targeted audience in a way that is in accordance to the donors' expectations.

Bennett and Barkensjo (2005) conform that the ability of a CO to motivate the feelings of trust in a charity's benevolence towards the individual will considerably affect a donor's willingness in a CO. Therefore, the perception of individuals on whether the $\mathrm{CO}$ has the ability to perform their job is crucial in choosing the organisation to monetary donation. Besides, previous research has proposed that perceived ability, perceived integrity, and perceived benevolence play a significant role in building individuals' trust in a CO (Alhidari, 2014). Thus, there is a significant relationship between these variables and the intention of forming a particular philanthropic behaviour.

H1: Perceived ability has a positive relationship with an individual's attitude towards a CO.

\section{The Perceived Integrity of Charitable Organisation}

The relationship between trust and integrity is important in establishing any kind of exchange or trade. Integrity refers to the trustor's perception that the trustee will follow the specific principles or guidelines of trade acceptable to the trustor during and after the trade (Mayer et al., 1995). Meanwhile, a trustor perceives that integrity grants assurance in trustee's behaviour and reduces perceptions of risk. Furthermore, perceived integrity or any other related concepts have been deliberated as an antecedent to trust by many theorists in the past researches (Mayer et al., 1995). In the charitable perspective, the expectations of integrity will be consistent over time, depending on the credibility of communication. This can be seen from the appropriate use of words and actions during communication, and commitment to ethical standards (Le Berre, 2010). It is important that a CO possesses certain criteria of integrity in order to gain the donor's trust. On the other hand, the donors' perceptions on whether their donation will be used appropriately and in accordance to the charity's mission are crucial in supporting COs (Tonkiss \& Passey, 1999; van Iwaarden, van der Wiele, Williams, \& Moxham, 2009). This perception includes the proportion of their donations that are spent on individual's salaries and fundraising activities (Sargeant, Ford, \& West, 2006).

H2: Perceived integrity has a positive relationship with an individual's attitude towards a CO. 


\section{The Perceived Benevolence of Charitable Organisation}

It is apparent that benevolent characteristics, such as caring, helpful, supportive, compassionate, fair, ethical, honest, and trustworthy, are all the traits associated with the notion of charity. Mayer et al. (1995) defined perceived benevolence as the extent to which a trustee is believed to be good to the trustor, rather than having an egocentric profit-based motive. Furthermore, benevolence introduces faith and altruism in a relationship, which reduces feelings of uncertainty and the inclination to guard against opportunistic behaviours' (Bhattacherjee, 2002). Besides, Le Berre (2010) argues that perceived ability and integrity are considered to hold a more significant role during the early stages of a relationship in most organisational settings. However, it is also argued by this scholar that from the outset of the relationship, benevolence plays a distinctive role in developing an individual's trust in the context of a CO. Moreover, the belief that is instilled in an individual's benevolence can reduce the chances of one to fall victim to opportunistic actions. This is achieved through the faith built in a relationship and the absence of uncertainties. On the other hand, benevolence from the donor's perspective in developing country is a critical issue of building trust in COs, as there might be no regulations that are set to control and monitor COs (Othman, Ali, Omar, \& Abdul Rahman, 2012).

H3: Perceived benevolence has a positive relationship with an individual's attitude towards a $\mathrm{CO}$.

\section{Personal Trust Disposition}

Trust disposition has a significant impact on the initial formation of trust. According to Ridings, Gefen, and Arinze (2002), trust disposition is another antecedent of trust. Disposition to trust is defined as an overall readiness established on extended socialisation to depend on others (McKnight, Cummings, \& Chervany, 1998; Ridings et al., 2002) and has been found to related to trust (Gefen, 2000; Mayer et al., 1995). This is because consumers may vary in terms of their readiness to trust others when they lack of sufficient information, especially when they are under an unfamiliar situation (Gefen, 2000). Furthermore, trust disposition is illustrated as one of the important factors in determining the philanthropic behaviours displayed by individuals in monetary donation. Besides, it is also explained by psychologists that trust is referred as a predisposition for an individual to believe others (Gefen, 2000; Rotter, 1967); whereas, social psychologists view trust as a cognition developed by the trustor regarding the trustee (Rempel, Holmes, \& Zanna, 1985). On the other hand, sociologists see trust as a characteristic of the institutional environment (Zucker, 1986). Disposition to trust is also referred to 
as trust propensity, and it is also defined as the general tendency of individuals to express faith or belief in humanity and adopting a trusting stance towards others (Gefen, 2000; Ridings et al., 2002). People may have different degrees of trust towards the same signals. As a result, the tendency of displaying personal trust may positively affect the trust being displayed (Lee \& Turban, 2001).

The existing study has demonstrated the significance of trust disposition in influencing an individual's attitude towards COs and their philanthropic behaviour (Alhidari, 2014; Knowles, Hyde, \& White, 2012; Oosterhof, Heuvelman, \& Peters, 2009). This is due to the barriers such as distance between donor and recipients as donor. To illustrate this, donors usually make their donations in order to help the needy through COs, instead of making direct donations to the people in need. Therefore, donors need to instill their trust in the COs in order to make their selected COs a platform to carry out the philanthropic donation. In general, the trust disposition in COs, which is displayed by donors, reflects the credibility and trustworthiness of a particular $\mathrm{CO}$. These qualities are often required by public and society, in order for them to value the CO's social and moral roles. Following this, COs will gain continuous support by having their roles appreciated (Sargeant et al., 2004). This view was later supported by Sargeant et al. (2006), who illustrates that the donor's trust is affected by the CO's performance and communication. However, interestingly, a donor's trust is not affected by the CO's responsiveness. In addition, individuals tend to trust those COs that are perceived to have an impact on a charitable cause.

H4: Trust disposition has a positive relationship with an individual's attitude towards a CO.

\section{Individual's Attitude towards Charitable Organisation}

Numerous literatures have shown that attitude is the manifestation of the behavioural intention of an individual's charitable behaviour, which includes blood donation (Giles, Mcclenahan, Cairns, \& Mallet, 2004), organ donation (Hyde \& White, 2009), bone marrow donation (Bagozzi, Lee, \& Van Loo, 2001), and monetary donations (Smith \& McSweeney, 2007; Webb, Green, \& Brashear, 2000). In the case of monetary donation, which is held through $\mathrm{CO}$, the attitudes displayed towards $\mathrm{CO}$ is a key in determining the monetary donation. Furthermore, Knowles et al. (2012, p. 300) states that the donor's attitude towards CO is defined as "global and relative endurance evaluations, with regards to the non-profit organizations that help the individuals in need." 
Ranganathan and Henley (2008) have reported that, in order to survive in the competition among other $\mathrm{COs}$ in the market, COs need to depend more on individual donors, in comparison to their dependency on the government for fundraising. There are different perceptions held by different individuals in regards to non-profit organisations (Awan \& Hameed, 2014).

Donors usually make their donation through $\mathrm{CO}$, as a result of the barriers created between donors and recipients. Therefore, a good attitude towards $\mathrm{CO}$ is important among the donors, for the donation process needs to be carried out swiftly. Furthermore, the donors' trust in their endorsed CO is critical (Keirouz, 1998; Ritchie et al., 1999), and they must hold a belief in the CO's ability of turning the donation process into a success (Laidler-Kylander et al., 2007). Similarly, Sargeant (1999) has found that the donor's philanthropic behaviour is highly dependent on their past experiences with the $\mathrm{CO}$ and their satisfaction level with the standard of service provided in the previous $\mathrm{CO}$.

A number of scholars state that the donor's attitude towards $\mathrm{CO}$ is one of the key factors of determining the donor's philanthropic behaviour (Veludo-de-Oliveira, Alhaidari, Yani-de-Soriano, \& Yousafzai, 2017). However, a situation that contradicts the views presented by the previous literature has occurred. Based on a study conducted by Bartolini (2005), it has been found that the donor's attitude towards $\mathrm{CO}$ does not reflect their philanthropic behavioural intention. However, the donor's attitude towards $\mathrm{CO}$ does act as a mediator in the relationship between donor's emotion and philanthropic behavioural intention (Bartolini, 2005). In other words, the donor's emotion of happiness and compassion is the key factor of philanthropic behavioural intention. In addition, those emotions are mediated by the donor's attitude towards a CO. Therefore, in this study, hypotheses have been drawn, which state that predictors, such as trust deposition, perceived ability, perceived integrity, and perceived benevolence, have positive effects on the donor's attitude towards COs. Last but not least, they act as a mediator towards philanthropic behaviour.

H5: The donor's attitude towards a $\mathrm{CO}$ has a positive relationship with monetary philanthropic behaviours.

H6: The perceived ability of donor's has a positive relationship with monetary philanthropic behaviours.

H7: The perceived integrity of $\mathrm{CO}$ has a positive relationship with monetary philanthropic behaviours. 
H8: The perceived benevolence has a positive relationship with monetary philanthropic behaviours.

H9: Trust disposition has a positive relationship with monetary philanthropic behaviours.

H10: The donor's attitude towards CO mediates the relationship between perceived ability and monetary philanthropic behaviours.

H11: The donor's attitude towards $\mathrm{CO}$ mediates the relationship between perceived integrity and monetary philanthropic behaviours.

H12: The donor's attitude towards $\mathrm{CO}$ mediates the relationship between perceived benevolence and monetary philanthropic behaviours.

H13: Attitude towards $\mathrm{CO}$ mediates the relationship between trust disposition and monetary philanthropic behaviours.

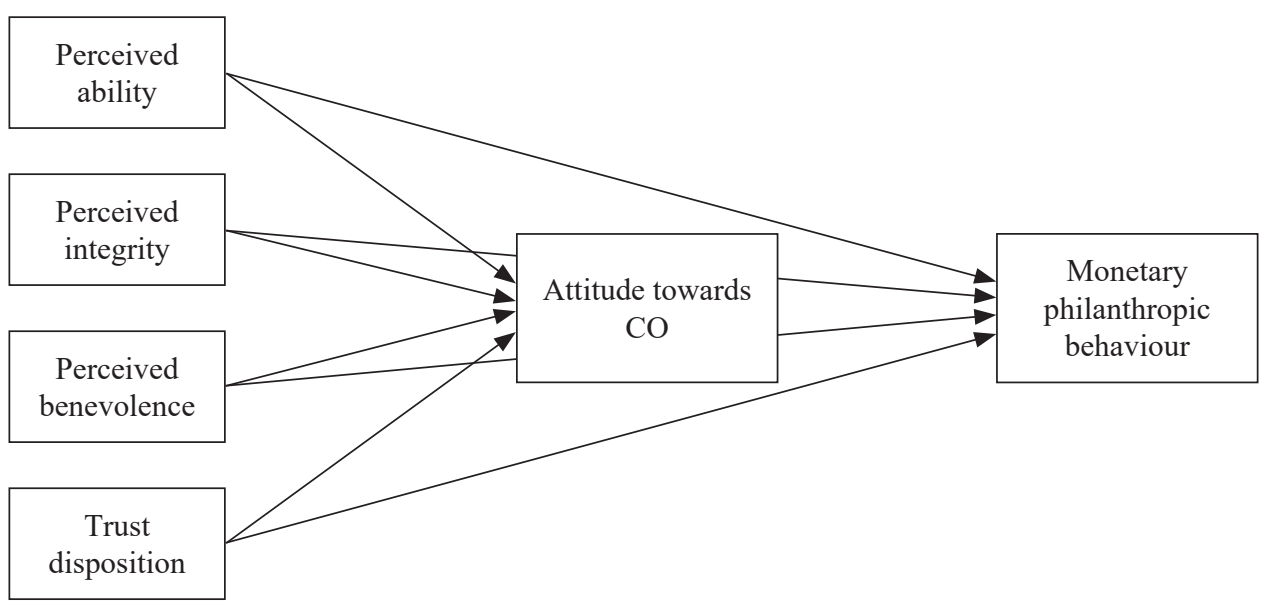

Figure 1. Research model

\section{METHODOLOGY}

The unit of analysis for this study was Generation-Y (Gen-Y), specifically those who were currently working or pursuing their studies in the main campus of Universiti Sains Malaysia (USM). USM has been chosen since most of the residents in USM came from various states of Malaysia and with diverse background. The sampling method adopted was non-probability convenience sampling method, which was 
incorporated with purposive sampling technique in sample selection. Purposive sampling technique was used as out of all respondents, only those who had previously made monetary donations via COs were selected. A set of prescreening questions were asked before questionnaires were answered by the respondents. Moreover, the prescreening questions were concerning on whether respondents had ever donated their money via COs. Provided if their answer was yes, they would be required to name the particular $\mathrm{CO}$ before answering the questionnaire. Then, a total of 258 usable questionnaires were gathered. The items for the measurement were adopted from previous literatures for each variables. Trust disposition items were derived from Lee and Turban (2001), perceived ability from Bhattacherjee (2002), perceived integrity from McKnight et al. (1998), perceived benevolence from Sargeant and Lee (2002a), attitude towards COs from Bartolini (2005) and Bhattacherjee (2002), and philanthropic behaviour from Bartolini (2005) and Oosterhof et al. (2009). The data gathered from the questionnaires was coded using IBM SPSS software version 19. This was followed by an analysis using SmartPLS 3.2.6.

PLS path modelling is a valid tool for structural equation modelling. According to Hair, Hollingsworth, Randolph, and Chong (2017) PLS-SEM can be used for the following four reasons: (1) the research objective is a confirmation of theory based on total variance, (2) the structural and measurement model is complex (many constructs, items, hypotheses), (3) the data was not normally distributed, and (4) the measurement of philosophy is in estimation with the composite factor model using total variance. Thus, in this study the PLS path was used due to the complexity of the model and to confirmed previous literature on trust based on total variance.

\section{DATA ANALYSIS}

A total of 258 questionnaires were gathered from the respondents. They were the representations of Gen-Y in Malaysia, who consisted of consumers with the range of age from 20 to 40 years old. Based on the prescreening questions, some of the COs listed by respondents are Mercy Malaysia, UNICEF, Aman Palestin, World Wide Fund for Nature (WWF) Malaysia, St. John Ambulance of Malaysia, Islamic Relief Malaysia, and welfare club or foundation such as Islamic schools, old folks homes, and orphanage houses. Following that, the demographic profile of respondents was analysed. Based on the analysis, it was shown that 139 (53.9\%), which was the majority of the respondents, were 20 to 25 years old, followed by 60 respondents who were 26 to 30 years old $(23.3 \%), 28$ respondents who were 31 to 35 years old $(10.9 \%), 21$ respondents who were 36 to 40 years old 
$(12.1 \%)$, and $4 \%$ of other respondents who were 41 years old and older. Apart from that, 177 of the respondents $(68.6 \%)$ were single, while 81 of the respondents $(31.4 \%)$ were married. Moreover, the education level of respondents was relatively high. To illustrate this, $66.7 \%$ of the respondents (172 respondents) were degree holders, followed by 53 respondents $(20.5 \%)$ who graduated from higher school (STPM/diploma/matriculation), 21 respondents $(8.1 \%)$ who were SPM (Malaysian Certificate of Education) leavers, and $4.7 \%$ of respondents who owned a postgraduate certificate (master's degree/ $\mathrm{PhD}$ ). In addition, the majority of the respondents were Malays ( 181 respondents, $70.2 \%$ ), followed by 53 Chinese $(20.5 \%), 22$ Indian $(8.5 \%)$, and 2 of the respondents who were from other ethnic backgrounds $(0.8 \%)$. In this study, 185 of the respondents (71.7\%) were Muslims, 41 of them (15.9\%) were Buddhists, 15 of them were Hindus $(5.8 \%)$, and 17 of them $(6.6 \%)$ were practitioners of other religions, for example, Christian. The profile of respondents is shown in Table 1.

Table 1

Respondent's profile

\begin{tabular}{llcc}
\hline Respondent's demographic profile & Frequency & Percent \\
\hline Age & $20-25$ & 139 & 53.9 \\
& $26-30$ & 60 & 23.3 \\
$31-35$ & 28 & 10.9 \\
& $36-40$ & 21 & 8.1 \\
Marital status & 41 and older & 10 & 3.8 \\
& Single & 177 & 68.6 \\
Education & Married & 81 & 31.4 \\
& SPM & 21 & 8.1 \\
& STPM/diploma/matrices & 53 & 20.5 \\
& Degree & 172 & 66.7 \\
Ethnics & Master & 11 & 4.3 \\
& PhD & 1 & 0.4 \\
& Malays & 181 & 70.2 \\
& Chinese & 53 & 20.5 \\
& Indian & 22 & 8.5 \\
& Others & 2 & 0.8 \\
& Islam & 185 & 71.7 \\
& Buddhism & 41 & 15.9 \\
& Hinduism & 15 & 5.8 \\
& Others & 17 & 6.6 \\
\hline \multirow{4}{*}{ Religion } & & &
\end{tabular}


Following the recommended two-stage analytical procedures by Anderson and Gerbing (1988), this study tested the measurement model then followed by the structural model. In order to test the significance of the path coefficients and the loadings, a bootstrapping (resampling $=5,000$ ) method was used (Hair, Marko, Lucas, \& Volker, 2014). Since the collected data was from one source, common method bias (CMB) maybe a concern. Harman's single factor test shows that the first factor explains $45.9 \%$ of the variance, which is less than $50 \%$ indicating CMB is not a serious problem. Recent editorial by Guide and Ketokivi (2015) have suggested that this is not a good method as such method suggested by Kock and Lynn (2012) is also used. Recent studies have proposed the assessment of both lateral and vertical collinearity among constructs when assessing a model (Kock \& Lynn, 2012; Rasoolimanesh, Jaafar, Kock, \& Ramayah, 2015). We used the full collinearity test as suggested by Kock and Lynn (2012) to test the CMB. First we need to create a new random variable which is coded 0 and 1 . Then all the constructs in the model are regressed against this new random variable and if the variance inflation factors (VIFs) are lower than 3.3, then CMB is not a serious issue. All the VIF values were lower than 3.3 suggesting that $\mathrm{CMB}$ is not a serious issue in this study.

\section{Measurement Model}

The measurement model with reflective indicators was modelled using SmartPLS 3.2.6 (Ringle, Wende, \& Will, 2005). It was then evaluated through an examination process conducted on the reliability and validity of the items and constructs. Based on the rule of thumb, a measurement model has a satisfactory reliability of internal consistency when the composite reliability (CR) of each construct exceeds the threshold value of 0.708 (Hair, Hult, Ringle, \& Sarstedt, 2016). Furthermore, all of the CR values in this model were beyond 0.708 . In addition, convergent validity was assessed by measuring the average variance extracted (AVE) values. As a result, it was shown that the AVE values for all constructs were beyond the threshold value of 0.50 , which indicated the satisfactory convergent validity.

Next, the indicator reliability of the measurement model was measured by examining the loading of each item. The amount of the loading should exceed the threshold value of 0.708 (Hair, Ringle, \& Sarstedt, 2011). Based on the analysis, all the items in the measurement model exhibited loading values that exceeded 0.700 . The exceeding values ranged from a lower bound of 0.723 to an upper bound of 0.927 , whereas, items TD2 and TD3 were deleted due to low value of loadings. The assessment conducted on the measurement model is presented in Table 2. Based on the results, all the constructs and items used for this study had demonstrated the satisfactory level of reliability and validity displayed by the measurement model. 
Siti Hasnah Hassan et al.

Table 2

Measurement model

\begin{tabular}{|c|c|c|c|c|}
\hline Constructs & Items & Loadings & AVE & $\mathrm{CR}$ \\
\hline \multirow{4}{*}{$\begin{array}{l}\text { Trust } \\
\text { disposition }\end{array}$} & TD1: I have trust in other people. & 0.803 & 0.570 & 0.888 \\
\hline & TD4: I have faith in humanity. & 0.723 & & \\
\hline & $\begin{array}{l}\text { TD5: I believe that people usually keep their } \\
\text { promises. }\end{array}$ & 0.783 & & \\
\hline & TD6: Most people are trustworthy. & 0.750 & & \\
\hline \multirow{8}{*}{$\begin{array}{l}\text { Perceived } \\
\text { ability }\end{array}$} & I believe that the COs stated above... & & & \\
\hline & $\begin{array}{l}\text { TPA1: skillful in safeguard my donated } \\
\text { money. }\end{array}$ & 0.812 & 0.722 & 0.948 \\
\hline & $\begin{array}{l}\text { TPA2: understand the needs of the } \\
\text { beneficiaries. }\end{array}$ & 0.819 & & \\
\hline & $\begin{array}{l}\text { TPA3: have the required knowledge to conduct } \\
\text { their activities. }\end{array}$ & 0.887 & & \\
\hline & $\begin{array}{l}\text { TPA4: are competent in conducting their } \\
\text { activities. }\end{array}$ & 0.874 & & \\
\hline & $\begin{array}{l}\text { TPA5: are effective in conducting their } \\
\text { activities. }\end{array}$ & 0.878 & & \\
\hline & $\begin{array}{l}\text { TPA6: have the ability to solve problems } \\
\text { faced. }\end{array}$ & 0.868 & & \\
\hline & $\begin{array}{l}\text { TPA7: are likely to have an impact on the } \\
\text { charitable donation. }\end{array}$ & 0.806 & & \\
\hline \multirow{6}{*}{$\begin{array}{l}\text { Perceived } \\
\text { integrity }\end{array}$} & I believe that the COs stated above... & & & \\
\hline & TPI1: are honest. & 0.853 & 0.770 & 0.944 \\
\hline & $\begin{array}{l}\text { TPI2: are truthful in their dealing with the } \\
\text { donors. }\end{array}$ & 0.897 & & \\
\hline & TPI3: have consistent practices. & 0.883 & & \\
\hline & TPI4: conduct their activities ethically. & 0.895 & & \\
\hline & TPI5: will keep their promises. & 0.858 & & \\
\hline \multirow{3}{*}{$\begin{array}{l}\text { Perceived } \\
\text { benevolence }\end{array}$} & I believe that the COs stated above... & & & \\
\hline & $\begin{array}{l}\text { TPB1: know the best interests of their } \\
\text { recipients. }\end{array}$ & 0.927 & 0.722 & 0.837 \\
\hline & $\begin{array}{l}\text { TPB2: always ask me for appropriate sums of } \\
\text { donation. }\end{array}$ & 0.765 & & \\
\hline
\end{tabular}


Table 2 (continued)

\begin{tabular}{|c|c|c|c|c|c|}
\hline Constructs & & Items & Loadings & AVE & $\mathrm{CR}$ \\
\hline \multirow{9}{*}{$\begin{array}{l}\text { Attitude } \\
\text { towards COs }\end{array}$} & ATCO1: & The stated CO is trustworthy. & 0.854 & \multirow[t]{9}{*}{0.731} & \multirow[t]{9}{*}{0.961} \\
\hline & ATCO2: & $\begin{array}{l}\text { The stated } \mathrm{CO} \text { uses donated funds } \\
\text { wisely. }\end{array}$ & 0.894 & & \\
\hline & ATCO3: & $\begin{array}{l}\text { The stated } \mathrm{CO} \text { does a good job in } \\
\text { meeting their mission. }\end{array}$ & 0.868 & & \\
\hline & ATCO4: & $\begin{array}{l}\text { Donations to the stated CO make a } \\
\text { difference. }\end{array}$ & 0.845 & & \\
\hline & ATCO5: & The image of the stated CO is good. & 0.849 & & \\
\hline & ATCO6: & $\begin{array}{l}\text { The stated CO is likely to have an } \\
\text { impact on the charitable donation. }\end{array}$ & 0.865 & & \\
\hline & ATCO7: & $\begin{array}{l}\text { The stated CO always offer help to } \\
\text { the needy. }\end{array}$ & 0.845 & & \\
\hline & ATCO8: & $\begin{array}{l}\text { The stated } \mathrm{CO} \text { is a reliable } \\
\text { organisation. }\end{array}$ & 0.867 & & \\
\hline & ATCO9: & $\begin{array}{l}\text { I endorse the help by means of the } \\
\text { stated CO. }\end{array}$ & 0.806 & & \\
\hline \multirow[t]{6}{*}{$\begin{array}{l}\text { Monetary } \\
\text { philanthropic } \\
\text { behaviour }\end{array}$} & MPB1: & $\begin{array}{l}\text { Intend to make monetary donation } \\
\text { to the stated } \mathrm{CO} \text { in the forthcoming } \\
\text { month. }\end{array}$ & 0.846 & \multirow[t]{6}{*}{0.741} & \multirow[t]{6}{*}{0.945} \\
\hline & MPB2: & $\begin{array}{l}\text { Would like to make monetary } \\
\text { donation to the stated CO in the } \\
\text { forthcoming month. }\end{array}$ & 0.884 & & \\
\hline & MPB3: & $\begin{array}{l}\text { Will recommend the stated } \mathrm{CO} \text { to } \\
\text { others. }\end{array}$ & 0.845 & & \\
\hline & MPB4: & $\begin{array}{l}\text { Will continue to make monetary } \\
\text { donation to the stated } \mathrm{CO} \text { in the } \\
\text { future. }\end{array}$ & 0.907 & & \\
\hline & MPB5: & $\begin{array}{l}\text { Will continue to make monetary } \\
\text { donation in order to make this world } \\
\text { a better place for the next generation. }\end{array}$ & 0.859 & & \\
\hline & MPB6: & $\begin{array}{l}\text { Philanthropic behaviour is the } \\
\text { responsibility of a good citizen. }\end{array}$ & 0.822 & & \\
\hline
\end{tabular}

Notes: TD2, TD3 were deleted due to low loadings; ATC: attitude towards CO; MPB: monetary philanthropic behaviour; TD: trust disposition; TPA: perceived ability; TPB: perceived benevolence TPI: perceived integrity

Furthermore, discriminant validity was evaluated through the assessment on cross loading and Fornell-Larcker criterion. Based on the rule of thumb, the amount of an indicator's outer loadings on a construct should be higher than the amount of its cross loadings with other constructs (Hair et al., 2016). Table 3 shows the amount of cross loadings of all items, and it can be seen that there was no problem occurring with discriminant validity. 
Siti Hasnah Hassan et al.

Table 3

Loadings and cross loadings for all constructs

\begin{tabular}{|c|c|c|c|c|c|c|}
\hline & ATC & MPB & TD & TPA & ТРВ & TPI \\
\hline ATCO1 & 0.854 & 0.615 & 0.333 & 0.705 & 0.543 & 0.639 \\
\hline ATCO2 & 0.894 & 0.528 & 0.348 & 0.712 & 0.585 & 0.664 \\
\hline ATCO3 & 0.868 & 0.521 & 0.325 & 0.68 & 0.577 & 0.651 \\
\hline ATCO4 & 0.845 & 0.564 & 0.310 & 0.698 & 0.568 & 0.631 \\
\hline ATCO5 & 0.849 & 0.524 & 0.271 & 0.659 & 0.594 & 0.671 \\
\hline ATCO6 & 0.865 & 0.571 & 0.331 & 0.663 & 0.562 & 0.636 \\
\hline ATCO7 & 0.845 & 0.492 & 0.297 & 0.654 & 0.524 & 0.599 \\
\hline ATCO8 & 0.867 & 0.514 & 0.309 & 0.647 & 0.509 & 0.569 \\
\hline ATCO9 & 0.806 & 0.464 & 0.289 & 0.582 & 0.549 & 0.580 \\
\hline PB1 & 0.481 & 0.846 & 0.305 & 0.465 & 0.400 & 0.377 \\
\hline PB2 & 0.502 & 0.884 & 0.326 & 0.461 & 0.410 & 0.367 \\
\hline PB3 & 0.490 & 0.845 & 0.279 & 0.463 & 0.438 & 0.374 \\
\hline PB4 & 0.560 & 0.907 & 0.307 & 0.554 & 0.491 & 0.452 \\
\hline PB5 & 0.604 & 0.859 & 0.339 & 0.605 & 0.432 & 0.498 \\
\hline PB6 & 0.571 & 0.822 & 0.310 & 0.542 & 0.448 & 0.492 \\
\hline TD1 & 0.301 & 0.333 & 0.803 & 0.37 & 0.304 & 0.340 \\
\hline TD2 & 0.103 & 0.209 & 0.722 & 0.183 & 0.14 & 0.163 \\
\hline TD3 & 0.122 & 0.212 & 0.744 & 0.19 & 0.171 & 0.177 \\
\hline TD4 & 0.437 & 0.376 & 0.723 & 0.562 & 0.417 & 0.496 \\
\hline TD5 & 0.248 & 0.158 & 0.783 & 0.316 & 0.268 & 0.294 \\
\hline TD6 & 0.200 & 0.185 & 0.750 & 0.273 & 0.211 & 0.245 \\
\hline TPA1 & 0.657 & 0.517 & 0.437 & 0.812 & 0.575 & 0.630 \\
\hline TPA2 & 0.623 & 0.543 & 0.467 & 0.819 & 0.568 & 0.710 \\
\hline TPA3 & 0.659 & 0.521 & 0.452 & 0.887 & 0.622 & 0.708 \\
\hline TPA4 & 0.642 & 0.505 & 0.394 & 0.874 & 0.614 & 0.675 \\
\hline TPA5 & 0.724 & 0.526 & 0.352 & 0.878 & 0.615 & 0.712 \\
\hline TPA6 & 0.698 & 0.484 & 0.391 & 0.868 & 0.679 & 0.704 \\
\hline TPA7 & 0.638 & 0.486 & 0.365 & 0.806 & 0.64 & 0.694 \\
\hline ТРВ1 & 0.686 & 0.497 & 0.364 & 0.566 & 0.927 & 0.622 \\
\hline ТРВ2 & 0.358 & 0.344 & 0.265 & 0.395 & 0.765 & 0.406 \\
\hline TPI1 & 0.672 & 0.463 & 0.410 & 0.730 & 0.675 & 0.853 \\
\hline TPI2 & 0.623 & 0.446 & 0.419 & 0.739 & 0.668 & 0.897 \\
\hline TPI3 & 0.645 & 0.407 & 0.327 & 0.701 & 0.683 & 0.883 \\
\hline TPI4 & 0.649 & 0.444 & 0.359 & 0.714 & 0.699 & 0.895 \\
\hline TPI5 & 0.630 & 0.430 & 0.383 & 0.681 & 0.659 & 0.858 \\
\hline
\end{tabular}


The square root value of AVE of each construct should be higher than the highest value of its correlation with any other construct, in order to obtain satisfactory discriminant validity. Table 4 indicates that the values of all the off-diagonal elements are lower than the value of square roots of the AVE (bolded on the diagonal). Therefore, based on the results, it was confirmed that Fornell and Larcker (1981) criterion was met.

Table 4

Fornell-Larcker criterion analysis

\begin{tabular}{lcccccc}
\hline \multicolumn{1}{c}{ Constructs } & 1 & 2 & 3 & 4 & 5 & 6 \\
\hline 1. ATC & $\mathbf{0 . 8 5 5}$ & & & & & \\
2. MPB & 0.625 & $\mathbf{0 . 8 6 1}$ & & & & \\
3. TD & 0.366 & 0.362 & $\mathbf{0 . 7 5 5}$ & & & \\
4. TPA & 0.781 & 0.603 & 0.480 & $\mathbf{0 . 8 5 0}$ & & \\
5. TPB & 0.651 & 0.509 & 0.378 & 0.725 & $\mathbf{0 . 8 5 0}$ & \\
6. TPI & 0.734 & 0.500 & 0.433 & 0.793 & 0.772 & $\mathbf{0 . 8 7 8}$ \\
\hline
\end{tabular}

Note: Values in the diagonal (bold) are square root of the AVE while the off-diagonals are correlations

All of the reliability and validity tests were confirmed once all indicators that were used in the measurement model for this study was valid and fit to be used for the estimation conducted on the parameters in the structural model.

\section{Structural Model}

The following subsections discussed on the tests that were used, in order to assess the validity of the structural model utilised for this study. Furthermore, the validity of the structural model was assessed through path coefficients and the coefficient of determination $\left(\mathrm{R}^{2}\right)$. In addition, the assessment on the relationship between the mediators, which was proposed in the research model, was conducted in this study.

\section{Direct effects}

Hypothesis testing analysis was carried out by bootstrapping 5,000 sub-samples, in order to evaluate the direct relationship between trust disposition, perceived ability, perceived integrity, perceived benevolence, and the donor's attitude towards COs. Based on the results presented in Table 5, it can be concluded that hypotheses $\mathrm{H}_{1}, \mathrm{H}_{2}, \mathrm{H}_{3}, \mathrm{H}_{5}, \mathrm{H}_{6}, \mathrm{H}_{7}, \mathrm{H}_{8}$, and $\mathrm{H}_{9}$ were supported. However, hypothesis $\mathrm{H}_{4}$ was not supported. Moreover, the results indicated that perceived ability, perceived integrity, and perceived benevolence posed influence on the donor's attitude towards COs at a different magnitude. Following that, the donor's attitude towards 
COs had a strong influence on monetary philanthropic behaviour $(\beta=0.413$, $p<0.01)$. Among the constructs, perceived ability was the strongest influential factor, which positively affected the donor's attitude towards COs $(\beta=0.531$, $p<0.01)$. This was followed by perceived integrity $(\beta=0.250, p<0.01)$, and perceived benevolence $(\beta=0.085, p<0.10)$. However, in contrast with what had been stated by the hypothesis proposed, trust disposition did not influence the donor's attitude towards COs. All the constructs had a direct effect on monetary philanthropic behaviour with perceived ability, perceived benevolence, perceived integrity, and trust disposition have a positive effect.

Table 5

Hypothesis testing

\begin{tabular}{clrrrrrr}
\hline Hypothesis & \multicolumn{1}{c}{ Relationship } & $\begin{array}{c}\text { Std. } \\
\text { beta }\end{array}$ & $\begin{array}{c}\text { Std. } \\
\text { error }\end{array}$ & $t$-value & $p$-value & LL & UL \\
\hline H1 & TPA $\rightarrow$ ATC & 0.531 & 0.063 & 8.395 & 0.000 & 0.432 & 0.636 \\
H2 & TPI $\rightarrow$ ATC & 0.250 & 0.080 & 3.104 & 0.001 & 0.113 & 0.384 \\
H3 & TPB $\rightarrow$ ATC & 0.085 & 0.050 & 1.702 & 0.045 & 0.012 & 0.172 \\
H4 & TD $\rightarrow$ ATC & -0.029 & 0.035 & 0.831 & 0.203 & -0.112 & -0.002 \\
H5 & ATC $\rightarrow$ MPB & 0.413 & 0.097 & 4.269 & 0.000 & 0.238 & 0.565 \\
H6 & TPA $\rightarrow$ MPB & 0.274 & 0.108 & 2.527 & 0.006 & 0.099 & 0.445 \\
H7 & TPI $\rightarrow$ MPB & 0.178 & 0.093 & 1.907 & 0.029 & 0.089 & 0.360 \\
H8 & TPB $\rightarrow$ MPB & 0.139 & 0.079 & 1.754 & 0.040 & 0.019 & 0.278 \\
H9 & TD $\rightarrow$ MPB & 0.104 & 0.057 & 1.815 & 0.035 & 0.022 & 0.209 \\
H10 & TPA $\rightarrow$ ATC $\rightarrow$ MPB & 0.219 & 0.058 & 3.788 & 0.000 & 0.113 & 0.324 \\
H11 & TPI $\rightarrow$ ATC $\rightarrow$ MPB & 0.103 & 0.044 & 2.345 & 0.019 & 0.034 & 0.203 \\
H12 & TPB $\rightarrow$ ATC $\rightarrow$ MPB & 0.035 & 0.025 & 1.382 & 0.167 & -0.013 & 0.091 \\
H13 & TD $\rightarrow$ ATC $\rightarrow$ MPB & -0.012 & 0.020 & 0.583 & 0.560 & -0.056 & 0.025 \\
\hline
\end{tabular}

Note: $\mathrm{LL}=$ lower limit; $\mathrm{UL}=$ upper limit

\section{Mediating effects}

To test the mediating effects, bootstrapping was carried out in order to distribute the sampling of the indirect effects using 5,000 sub-samples, as suggested by Hair et al. (2016). This was followed by the steps introduced by Preacher and Hayes (2008). As a result, the bootstrapping analysis indicated that two of the paths, which were perceived ability $\rightarrow$ attitude towards $\mathrm{CO} \rightarrow$ monetary philanthropic behaviour $(\beta=0.219)$, and perceived integrity $\rightarrow$ attitude towards $\mathrm{CO} \rightarrow$ monetary philanthropic behaviour $(\beta=0.103)$ were significant, with a $t$-value of 3.788 and 2.345 respectively. It was also found from the results that the donor's attitude towards 
COs did not give a significant effect on the relationship between an individual's philanthropic behaviour with trust disposition and perceived benevolence.

Furthermore, according to Preacher and Hayes (2008), a mediating effect emerges, provided when the indirect effects amount to $95 \%$ of bootstrap confidence interval (CI), and this amount do not straddle a 0 in between. Therefore, it can be concluded that $\mathrm{H}_{10}$ and $\mathrm{H}_{11}$ were statistically significant. This conclusion has indicated that the donor's attitude towards COs has a mediating effect on the relationship between an individual's philanthropic behaviour with perceived ability and perceived integrity (Table 5).

\section{DISCUSSION}

Based on the results, it can be seen that perceived ability and perceived integrity have proven to pose a strong significant impact on the donor's attitude towards a $\mathrm{CO}$ and followed by perceived benevolence. The result from the research was consistent with the findings discovered by other researchers, such as Morgan and Hunt (1994), Alhidari (2014), and Le Berre (2010). These are the researchers who stipulated that perceived ability, perceived integrity, and perceived benevolence give impact on the donor's attitude towards CO. Furthermore, these factors are the antecedents to trust instilled within the $\mathrm{CO}$ and support the trust theory. In fact, a $\mathrm{CO}$ is considered as trustworthy if it possesses the skills, knowledge, and resources (ability) to make use of the donations in adherence to the specified purpose. Besides, they will use their funds by appropriate means and in a manner that is in accordance to the charity's mission (integrity), and they will use the donation for the benefit of needy people (benevolence).

Besides, the results of this research support the findings that the donor's attitude towards $\mathrm{CO}$ has a positive influence on individual's philanthropic behaviour. In other words, individuals will have the tendency of displaying philanthropic behaviour, provided that the $\mathrm{CO}$ is trustworthy. Although the results of this study have confirmed the results of previous studies, there is a slight contradiction in the findings from this study with the findings discovered from the research conducted by Pentecost and Andrews (2010). To illustrate this, the research conducted by Pentecost and Andrews (2010) has found that the donor's attitude towards CO poses no significant effects on any charitable behaviours. This was based on one of their samples, who was a non-student (there were two types of samples used in the research conducted, namely student and non-student). On the contrary, this research has shown that through the improvement of the donor's attitude towards the $\mathrm{CO}$, a stronger intention of displaying philanthropic behaviours among 
individuals will occur. Additionally, the relationship between the donor's attitude towards the $\mathrm{CO}$ and philanthropic behaviour suggests that the donor's attitude towards $\mathrm{CO}$ is necessary in leading individuals towards philanthropic behaviours. This has indicated that consumers are somehow more willing to give and provide for public good.

Last but not least, the donor's attitude towards $\mathrm{CO}$ has proven to be the important mediators of the relationship between perceived ability, perceived integrity, and monetary philanthropic behaviour in this study. During the research, when the mediator test was run, the findings of the study have clearly proven that the donor's attitude towards $\mathrm{CO}$ holds a mediating role in the link between perceived ability and monetary philanthropic behaviour. It also plays a role in the relationship between perceived integrity and monetary philanthropic behaviour. Moreover, it has been found that individual personal trust disposition has a non-significant relationship with the donor's attitude towards a $\mathrm{CO}$.

In addition, the results of this research have provided several important insights on monetary philanthropic behaviour displayed by individuals. As observed in this study, perceived ability, perceived integrity, and perceived benevolence are the important factors needed for the improvement of the donor's attitude towards a $\mathrm{CO}$ and philanthropic behaviour. Apart from that, due to the finding that the donor's attitude towards $\mathrm{CO}$ has a positive effect on individual's philanthropic behaviour, charity marketers need to acquire a better understanding in regards of individual's attitude towards a CO. Furthermore, the marketing activities that are organised for charity purposes should pay the efforts required to improve individual's perception on the charity. This can be done by enhancing the organisation's reputation, performance, and their communication with the public. However, based on the results of this research, it has been shown that further research is needed for the improvement of the theoretical model. This improvement is essential for the acquirement of a better predictive value of individual's monetary philanthropic behaviour.

Besides, it is also recommended that future studies should extend this research in order to include more variables that have not been covered in this study, such as subjective norms, social norms, moral responsibilities, religious beliefs, donor's past experiences, and so on. Apart from that, it is also possible for future studies to consider focusing on the more comprehensive multidimensional frameworks. Furthermore, studies can also be conducted by taking the organisation's reputation, donor's familiarity, and organisations' communication into consideration, in the 
efforts of improving individual's attitude towards CO. Meanwhile, donor trust can be acquired by $\mathrm{CO}$. This can be achieved through the improvement of the organisation's reputation, and the reinforcement of the donor's familiarity to the public through effective communication between the organisation and the donor.

In addition, it is also recommended that an extended research is conducted in order to measure the continued philanthropic behaviour displayed by individuals. To illustrate this, during the time when these generations have grown up and started to earn a stable income, their philanthropic behaviour might change.

Last but not least, replication is another area that future studies should look into. The reported study should be replicated with additional samples with different settings, such as different culture contexts. This is because people who originate from high context culture might behave differently compared to those from the low context culture.

\section{CONCLUSION}

In conclusion, the findings of this study shed some useful insight to scholars and practitioners in the non-profit marketing and consumer behaviour fields. This study could help COs in targeting their potential donors when assistance is needed from the public. Furthermore, this study provided further understanding to scholars and practitioners regarding the influence of trust on individual's philanthropic behaviour that is displayed during a monetary donation. This understanding is important, especially to a non-profit organisation such as COs. This is because they are required to outline their marketing strategies and plans in order to get support and instill the value of giving and helping the people in need among young generations. Trust is seen as a dynamic, directional, measurable, and changeable concept. By understanding and measuring antecedents of trust, COs are able to differentiate among donors who have low trust levels to those who have high trust levels. The knowledge will help COs to form different marketing strategies to create, recover, or maintain trust among its current and prospective donors. Individual, trust changes over time, and hence, any negative media report of poor performance or misallocation of funds in a $\mathrm{CO}$ can easily affect public distrust. Thus, COs must always assure the public and reinforce their reputation on how they are performing using any mean of communication tools, either it is print media or digital medias such as websites, blogs, and social media in reporting their daily activities in managing the funds. 


\section{ACKNOWLEDGEMENTS}

The authors would like to thank Universiti Sains Malaysia for the research grant provided (Research University Grant, USM, grant number 1001/PMGT/816211).

\section{REFERENCES}

Alhidari, I.S. (2014). Investigating individuals' monetary donation behaviour in Saudi Arabia. PhD dissertation, Cardiff University, United Kingdom.

Anderson, J.C., \& Gerbing, D.W. (1988). Structural equation modeling in practice: A review and recommended two-step approach. Psychological Bulletin, 103(3), 411. https://doi.org/10.1037/0033-2909.103.3.411

Awan, M.Y., \& Hameed, F. (2014). The effect of demographic, socio-economic and other characteristics on donations. Current Research Journal of Social Sciences, 6(2), $55-76$.

Bagozzi, R.P., Lee, K.-H., \& Van Loo, M.F. (2001). Decisions to donate bone marrow: The role of attitudes and subjective norms across cultures. Psychology and Health, 16(1), 29-56. https://doi.org/10.1080/08870440108405488

Bartolini, W.F. (2005). Prospective donors' cognitive and emotive processing of charitable gift requests. $\mathrm{PhD}$ dissertation, Kent State University, United States.

Bennett, R., \& Ali-Choudhury, R. (2009). Second-gift behaviour of first-time donors to charity: An empirical study. International Journal of Nonprofit and Voluntary Sector Marketing, 14(3), 161-180. https://doi.org/10.1002/nvsm.347

Bennett, R., \& Barkensjo, A. (2005). Causes and consequences of donor perceptions of the quality of the relationship marketing activities of charitable organisations. Journal of Targeting, Measurement and Analysis for Marketing, 13(2), 122-139. https://doi.org/10.1057/palgrave.jt.5740138

Bhattacherjee, A. (2002). Individual trust in online firms: Scale development and initial test. Journal of Management Information Systems, 19(1), 211-242. https://doi.or $\mathrm{g} / 10.1080 / 07421222.2002 .11045715$

Burgoyne, C.B., Young, B., \& Walker, C.M. (2005). Deciding to give to charity: A focus group study in the context of the household economy. Journal of Community \& Applied Social Psychology, 15(5), 383-405. https://doi.org/10.1002/casp.832

Burnett, K. (2002). Relationship fundraising: A donor-based approach to the business of raising money. New York: John Wiley \& Sons.

Fornell, C., \& Larcker, D.F. (1981). Structural equation models with unobservable variables and measurement error: Algebra and statistics. Journal of Marketing Research, 382-388. https://doi.org/10.2307/3150980

Gefen, D. (2000). E-commerce: The role of familiarity and trust. Omega, 28(6), 725-737. https://doi.org/10.1016/S0305-0483(00)00021-9

Giles, M., Mcclenahan, C., Cairns, E., \& Mallet, J. (2004). An application of the theory of planned behaviour to blood donation: The importance of self-efficacy. Health Education Research, 19(4), 380-391. https://doi.org/10.1093/her/cyg063 
Giving USA. (2013). The Annual Report on Philanthropy for the Year 2011. Indiana: The Centre on Philanthropy at Indiana University.

Giving USA. (2016). 2015 was America's most-generous year ever. Retrieved 20 June 2017 from https://givingusa.org/giving-usa-2016/

Grabner-Kräuter, S., \& Kaluscha, E.A. (2003). Empirical research in on-line trust: A review and critical assessment. International Journal of Human-Computer Studies, 58(6), 783-812. https://doi.org/10.1016/S1071-5819(03)00043-0

Guide, V.D.R., \& Ketokivi, M. (2015). Notes from the editors: Redefining some methodological criteria for the journal. Journal of Operations Management, 37, v-viii. https://doi.org/10.1016/S0272-6963(15)00056-X

Hair, J.F., Hollingsworth, C.L., Randolph, A.B., \& Chong, A.Y.L. (2017). An updated and expanded assessment of PLS-SEM in information systems research. Industrial Management \& Data Systems, 117(3), 442-458. https://doi.org/10.1108/IMDS04-2016-0130

Hair, J.F., Hult, G.T.M., Ringle, C., \& Sarstedt, M. (2016). A primer on partial least squares structural equation modeling (PLS-SEM). New York: Sage Publications.

Hair, J.F., Marko, S., Lucas, H., \& Volker, G.K. (2014). Partial least squares structural equation modeling (PLS-SEM): An emerging tool in business research. European Business Review, 26(2), 106-121. https://doi.org/10.1108/EBR-10-2013-0128

Hair, J.F., Ringle, C.M., \& Sarstedt, M. (2011). PLS-SEM: Indeed a silver bullet. Journal of Marketing Theory and Practice, 19(2), 139-152. https://doi.org/10.2753/ MTP1069-6679190202

Hou, J., Zhang, C., \& King, R.A. (2017). Understanding the dynamics of the individual donor's trust damage in the philanthropic sector. Voluntas: International Journal of Voluntary and Nonprofit Organizations, 28(2), 648-671. https://doi. org/10.1007/s11266-016-9681-8

Hsu, J.L., Liang, G.-Y., \& Tien, C.-P. (2005). Social concerns and willingness to support charities. Social Behavior and Personality: An International Journal, 33(2), 189200. https://doi.org/10.2224/sbp.2005.33.2.189

Hyde, M.K., \& White, K.M. (2009). To be a donor or not to be? Applying an extended theory of planned behavior to predict posthumous organ donation intentions. Journal of Applied Social Psychology, 39(4), 880-900. https://doi.org/10.1111/ j.1559-1816.2009.00464.x

Jones, K.S. (2006). Giving and volunteering as distinct forms of civic engagement: The role of community integration and personal resources in formal helping. Nonprofit and Voluntary Sector Quarterly, 35(2), 249-266. https://doi. org/10.1177/0899764006287464

Keirouz, K.S. (1998). Public perceptions and confidence in Indiana nonprofit organizations. Indianapolis: Indiana University Center of Philanthropy.

Knowles, S.R., Hyde, M.K., \& White, K.M. (2012). Predictors of young people's charitable intentions to donate money: An extended theory of planned behavior perspective. Journal of Applied Social Psychology, 42(9), 2096-2110. https://doi.org/10.1111/ j.1559-1816.2012.00932.x 
Kock, N., \& Lynn, G. (2012). Lateral collinearity and misleading results in variancebased SEM: An illustration and recommendations. Journal of the Association for Information System, 13(7), 546-580. https://doi.org/10.17705/1jais.00302

Laidler-Kylander, N., Quelch, J.A., \& Simonin, B.L. (2007). Building and valuing global brands in the nonprofit sector. Nonprofit Management and Leadership, 17(3), 253-277. https://doi.org/10.1002/nml.149

Le Berre, S. (2010). Global nonprofit brands: Whence the trust halo? Paper presented at the 7th Thought Leaders International Conference in Brand Management, Lugano, Switzerland.

Lee, M.K., \& Turban, E. (2001). A trust model for consumer internet shopping. International Journal of Electronic Commerce, 6(1), 75-92. https://doi.org/10.1080/10864415 .2001 .11044227

Lyons, M. (2001). Third sector: The contribution of nonprofit and cooperative enterprises in Australia. Sydney: Allen \& Unwin.

Mayer, R.C., Davis, J.H., \& Schoorman, F.D. (1995). An integrative model of organizational trust. Academy of Management Review, 20(3), 709-734. https://doi.org/10.5465/ AMR.1995.9508080335

McKnight, D.H., Cummings, L.L., \& Chervany, N.L. (1998). Initial trust formation in new organizational relationships. Academy of Management Review, 23(3), 473-490. https://doi.org/10.5465/AMR.1998.926622

Morgan, R.M., \& Hunt, S.D. (1994). The commitment-trust theory of relationship marketing. The Journal of Marketing, 58(3), 20-38. https://doi.org/10.2307/1252308

Oosterhof, L., Heuvelman, A., \& Peters, O. (2009). Donation to disaster relief campaigns: Underlying social cognitive factors exposed. Evaluation and Program Planning, 32(2), 148-157. https://doi.org/10.1016/j.evalprogplan.2008.10.006

Othman, R., Ali, N., Omar, N., \& Abdul Rahman, R. (2012). Practical challenges in managing non-profit organizations (NPO): Tales from two neighbouring countries. International Bulletin of Business Administration, (13), 6-23.

Payton, R.L. (1988). Philanthropy: Voluntary action for the public good. New York: American Council on Education New York.

Pentecost, R., \& Andrews, L. (2010). Differences between students and non-students' willingness to donate to a charitable organisation. International Journal of Nonprofit and Voluntary Sector Marketing, 15(2), 122-136.

Preacher, K.J., \& Hayes, A.F. (2008). Asymptotic and resampling strategies for assessing and comparing indirect effects in multiple mediator models. Behavior Research Methods, 40(3), 879-891. https://doi.org/10.3758/BRM.40.3.879

Radley, A., \& Kennedy, M. (1995). Charitable giving by individuals: A study of attitudes and practice. Human Relations, 48(6), 685-709. https://doi. org/10.1177/001872679504800605

Ramesh, R. (2011). Charitable giving by country: Who is the most generous? Retrieved 20 December 2016 from http://www.theguardian.com/news/datablog/2010/sep /08/ charitable-giving-country\#

Ranganathan, S.K., \& Henley, W.H. (2008). Determinants of charitable donation intentions: A structural equation model. International Journal of Nonprofit and Voluntary Sector Marketing, 13(1), 1-11. https://doi.org/10.1002/nvsm.297 
Ranganathan, S.K., \& Sen, S. (2012). Examining charitable donation process in South India: Role of gender. International Journal of Nonprofit and Voluntary Sector Marketing, 17(2), 108-121. https://doi.org/10.1002/nvsm.1413

Rasoolimanesh, S.M., Jaafar, M., Kock, N., \& Ramayah, T. (2015). A revised framework of social exchange theory to investigate the factors influencing residents' perceptions. Tourism Management Perspectives, 16, 335-345. https://doi. org/10.1016/j.tmp.2015.10.001

Rempel, J.K., Holmes, J.G., \& Zanna, M.P. (1985). Trust in close relationships. Journal of Personality and Social Psychology, 49(1), 95-112. https://doi.org/10.1037/00223514.49.1.95

Ridings, C.M., Gefen, D., \& Arinze, B. (2002). Some antecedents and effects of trust in virtual communities. The Journal of Strategic Information Systems, 11(3), 271295. https://doi.org/10.1016/S0963-8687(02)00021-5

Ringle, C.M., Wende, S., \& Will, A. (2005). SmartPLS 2.0 (beta). Hamburg: SmartPLS.

Ritchie, R.J., Swami, S., \& Weinberg, C.B. (1999). A brand new world for nonprofits. International Journal of Nonprofit and Voluntary Sector Marketing, 4(1), 26-42. https://doi.org/10.1002/nvsm.54

Rotter, J.B. (1967). A new scale for the measurement of interpersonal trust. Journal of Personality, 35(4), 651-665. https://doi.org/10.1111/j.1467-6494.1967.tb01454.x

Salamon, L.M. (2012). The state of nonprofit America. New York: Brookings Institution Press.

Sargeant, A. (1999). Charitable giving: Towards a model of donor behaviour. Journal of Marketing Management, 15(4), 215-238. https://doi. org/10.1362/026725799784870351

Sargeant, A., Ford, J.B., \& West, D.C. (2006). Perceptual determinants of nonprofit giving behavior. Journal of Business Research, 59(2), 155-165. https://doi.org/10.1016/j. jbusres.2005.04.006

Sargeant, A., \& Lee, S. (2002a). Improving public trust in the voluntary sector: An empirical analysis. International Journal of Nonprofit and Voluntary Sector Marketing, 7(1), 68-83. https://doi.org/10.1002/nvsm.168

Sargeant, A., \& Lee, S. (2002b). Individual and contextual antecedents of donor trust in the voluntary sector. Journal of Marketing Management, 18(7-8), 779-802. https:// doi.org/10.1362/0267257022780679

Sargeant, A., West, D.C., \& Ford, J.B. (2004). Does perception matter? An empirical analysis of donor behaviour. The Service Industries Journal, 24(6), 19-36. https:// doi.org/10.1080/0264206042000299167

Schuyt, T., Smit, J.H., \& Bekkers, R. (2013). Constructing a philanthropy-scale: Social responsibility and philanthropy. SSRN Electronic Journal, 501. https://doi. org/10.2139/ssrn.2274558

Shehu, E., Becker, J.U., Langmaack, A.-C., \& Clement, M. (2016). The brand personality of nonprofit organizations and the influence of monetary incentives. Journal of Business Ethics, 138(3), 589-600. https://doi.org/10.1007/s10551-015-2595-3 
Smith, J.R., \& McSweeney, A. (2007). Charitable giving: The effectiveness of a revised theory of planned behaviour model in predicting donating intentions and behaviour. Journal of Community \& Applied Social Psychology, 17(5), 363-386. https://doi.org/10.1002/casp.906

Stride, H. (2006). An investigation into the values dimensions of branding: Implications for the charity sector. International Journal of Nonprofit and Voluntary Sector Marketing, 11(2), 115-124. https://doi.org/10.1002/nvsm.44

Tonkiss, F., \& Passey, A. (1999). Trust, confidence and voluntary organisations: Between values and institutions. Sociology, 33(2), 257-274. https://doi.org/10.1177/ S0038038599000164

Van Iwaarden, J., van der Wiele, T., Williams, R., \& Moxham, C. (2009). Charities: How important is performance to donors? International Journal of Quality \& Reliability Management, 26(1), 5-22. https://doi.org/10.1108/02656710910924143

Veludo-de-Oliveira, T.M., Alhaidari, I.S., Yani-de-Soriano, M., \& Yousafzai, S.Y. (2017). Comparing the explanatory and predictive power of intention-based theories of personal monetary donation to charitable organizations. Voluntas: International Journal of Voluntary and Nonprofit Organizations, 28(2), 571-593. https://doi. org/10.1007/s11266-016-9690-7

Webb, D.J., Green, C.L., \& Brashear, T.G. (2000). Development and validation of scales to measure attitudes influencing monetary donations to charitable organizations. Journal of the Academy of Marketing Science, 28(2), 299-309. https://doi. org/10.1177/0092070300282010

Zucker, L.G. (1986). Production of trust: Institutional sources of economic structure, 1840-1920. Research in Organizational Behavior, 8, 53-111. 